\title{
Cobalamin Malabsorption in Three Siblings Due to an Abnormal Intrinsic Factor That Is Markedly Susceptible to Acid and Proteolysis
}

\author{
Yih-ming Yang, Rafael Ducos, Allen J. Rosenberg, and Paul G. Catrou \\ Departments of Pediatrics and Pathology, Louisiana State University Medical Center, New Orleans, Louisiana 70112
}

Joel S. Levine, Elaine R. Podell, and Robert H. Allen

Divisions of Hematology, Oncology, and Gastroenterology, Department of Medicine, School of Medicine, University of Colorado Health

Sciences Center, Denver, Colorado 80262

\begin{abstract}
Three siblings presented in their second year of life with megaloblastic anemia that responded to parenteral cobalamin (Cbl). Schilling tests were $<1 \%$, correcting to 5 to $15 \%$ after addition of hog intrinsic factor (IF). Gastric acid analysis and gastric biopsies were normal by light and electron microscopy. Gastric juice contained $<3 \mathrm{pmol} / \mathrm{ml}$ of Cbl-binding ability due to IF (normal, 10-34 pmol/ml) and $<2 \mathrm{pmol} / \mathrm{ml}$ of IF when measured with a radioimmunoassay (RIA) using normal human IF${ }^{57} \mathrm{Co} / \mathrm{Cbl}$ and rabbit anti-human IF serum (normal, 17-66 pmol/ ml). However, RIA employing rabbit anti-hog IF serum gave values of 4-13 $\mathrm{pmol} / \mathrm{ml}$ of IF (normal, 11-33 pmol/ml). This material had an apparent molecular weight of $\mathbf{4 0 , 0 0 0}$ (normal IF $=\mathbf{7 0 , 0 0 0 )}$.

The IF from gastric biopsies appeared normal in terms of Cbl-binding ability, ileal binding, molecular weight, and both RIAs. This IF differed from normal mucosal IF, in that it lost its $\mathrm{Cbl}$-binding ability when incubated at $37^{\circ} \mathrm{C}$ at acid $\mathrm{pH}$ or in the presence of pepsin or trypsin. This loss was retarded when $\left[{ }^{57} \mathrm{Co}\right] \mathrm{Cbl}$ was bound to the IF before these incubations. The stabilizing effects of neutralization and $\mathrm{Cbl}$ were also demonstrated in vivo. Schilling tests for the siblings of $0.4,0.5$, and $1.0 \%$ increased to $2.7,5.7$, and $4.3 \%(P<0.05)$, respectively, when the Schilling tests were repeated with the addition of $\mathrm{NaHCO}_{3}$ and cobinamide (which allows $\mathrm{Cbl}$ to bind immediately to IF).

We conclude that $\mathrm{Cbl}$ malabsorption in these children is due to an abnormal IF that is markedly susceptible to acid and proteolytic enzymes which cause a decrease in its molecular weight and Cbl-binding ability and a loss of antigenic determinants that are recognized by the anti-human IF serum.
\end{abstract}

\section{Introduction}

A number of children have been reported (1-22) who malabsorbed cobalamin $(\mathrm{Cbl})^{1}$ secondary to a congenital absence of functional intrinsic factor (IF). These children developed signs of $\mathrm{Cbl}$ deficiency before age five and had abnormal Schilling tests that corrected with the addition of IF. They differ from

Dr. Yang's present address is Department of Medicine, The Mennonite Christian Hospital, Meilun, Hwalien, Taiwan 950 R.O.C.

Received for publication 14 January 1985.

1. Abbreviations used in this paper: $\mathrm{Cbl}$, cobalamin; IF, intrinsic factor.

J. Clin. Invest.

(C) The American Society for Clinical Investigation, Inc. 0021-9738/85/12/2057/09 \$1.00

Volume 76, December 1985, 2057-2065 adults with pernicious anemia since their gastric mucosa and gastric acidity are normal and since they lack anti-IF and antiparietal cell antibodies in their sera.

Based on the existing knowledge of the process of IF-mediated $\mathrm{Cbl}$ absorption (23-25), it is clear that mutations in the structural gene for IF could cause a lack of functional IF by a variety of mechanisms. Such mutations could result in absent or decreased synthesis of IF by gastric parietal cells, or in a decrease in secretion of IF into gastric juice. Other mutations could result in IF molecules that have a decreased affinity for $\mathrm{Cbl}$ or an increase in susceptibility to alteration by acid or proteolytic enzymes such as pepsin, trypsin, chymotrypsin, etc. Additional mutations could result in IF molecules that have as their IF-Cbl complexes, a decrease in affinity for ileal IF-Cbl receptors. A structurally abnormal IF could also interfere with the poorly understood subsequent ileal phase of $\mathrm{Cbl}$ absorption, since at some point $\mathrm{Cbl}$ must be released from IF because IF does not appear to enter the portal blood.

One example of a structurally abnormal IF has been reported previously (26-27). This IF had a normal molecular weight, bound Cbl normally, and appeared to be normally resistant to alteration by acid or proteolytic enzymes. Immunologic studies demonstrated that the abnormal IF contained at least one antigenic determinant that was not present on normal IF. The abnormal IF-Cbl complex had a 60 -fold lower affinity for ileal receptors than did normal IF-Cbl. This markedly reduced, but not absent, affinity for ileal receptors correlated well with a markedly reduced, but not absent, ability to stimulate $\mathrm{Cbl}$ absorption in a subject with a total gastrectomy. It also correlated well with the fact that the patient did not develop signs of $\mathrm{Cbl}$ deficiency until age $13 \mathrm{yr}$.

We now report three siblings who have a second type of abnormal IF. Their parietal cells contain IF that binds $\mathrm{Cbl}$ and facilitates $\mathrm{Cbl}$ binding to ileal receptors in a normal manner. This IF is markedly susceptible to alteration by acid and proteolytic enzymes, however, and thus rapidly loses its functional ability in vivo in gastric juice. We also report on another child from a different family who appears to have a complete absence of IF in both parietal cells and gastric juice.

\section{Methods}

$\mathrm{CN}-\left[{ }^{57} \mathrm{Co}\right] \mathrm{Cbl}(200 \mu \mathrm{Ci} / \mathrm{nmobl}), \mathrm{CN}-\left[{ }^{58} \mathrm{Co}\right] \mathrm{Cbl}(4 \mu \mathrm{Ci} / \mathrm{nmol})$, Sepharose, Cbl-Sepharose $(0.7 \mu \mathrm{mol} / \mathrm{ml})$, purified human IF, rabbit anti-human IF, rabbit anti-hog IF, hog pepsin, and hog trypsin were obtained and prepared as described elsewhere $(26,28)$.

Basal and pentagastrin-stimulated gastric juice was collected on ice by nasal gastric suction and stored at $-20^{\circ} \mathrm{C}$ after neutralization to destroy pepsin. Cbl-binding ability was assayed in $0.1 \mathrm{M}$ potassium phosphate, pH 7.5, by modification (29) of the charcoal absorption technique of Gottlieb et al. (30). The amount of Cbl-binding ability due to IF was 
based on the amount of inhibition of Cbl-binding ability obtained with anti-IF blocking antibody obtained from the serum of a pernicious anemia patient. The amount of Cbl-binding ability due to $\mathrm{R}$ protein was based on the amount of inhibition of Cbl-binding ability observed with a 100-fold excess of cobinamide. Serum was assayed for anti-IF blocking antibody and anti-IF binding antibody as described (29). Anti-parietal cell antibodies were assayed by the indirect immunofluorescent method described by Roitt and Doniach (31). Schilling tests were performed as described (32) using $0.2 \mathrm{nmol} \mathrm{CN}-\left[{ }^{57} \mathrm{Co}\right] \mathrm{Cbl}$ dissolved in $10 \mathrm{ml}$ of 0.01 $\mathrm{M}$ potassium phosphate, $\mathrm{pH} 7.5$, containing $0.14 \mathrm{M} \mathrm{NaCl}$. Additional components, when given, consisted of nonradioactive cobinamide, 200 $\mathrm{nmol}$, which was dissolved in the solution containing the $\left[{ }^{57} \mathrm{Co}\right] \mathrm{Cbl}$, and $\mathrm{NaHCO}_{3}, 2.4 \mathrm{~g}$, which was given $1 \mathrm{~min}$ before the radioactive Cbl. Preparation and calibration of columns of Sephadex G-150, fine grade, was performed as described previously (29).

Gastric biopsies were obtained from patients in the basal state and after stimulation with pentagastrin $(6 \mu \mathrm{g} / \mathrm{kg}$ s.c.) using a suction biopsy tube, Quinton Instruments (Seattle, WA), that was positioned in the fundus by fluoroscopy. Gastric biopsies were obtained from normal young adults in the same manner, except that a hydraulic suction biopsy tube (Quinton Instruments) was employed. Biopsies were fixed, examined by light and electron microscopy, and examined for the immunocytochemical localization of IF, as described previously $(33,34)$. Biopsies were also added to $0.1 \mathrm{M}$ Tris- $\mathrm{HCl}, \mathrm{pH} 10.0(1 \mathrm{ml} / 100 \mathrm{mg}$ of tissue $)$ and stored at $-20^{\circ} \mathrm{C}$. After thawing, these samples were homogenized at $4^{\circ} \mathrm{C}$ with approximately 20 strokes of a motor-driven Teflon pestle in a fritted glass tube, and the supernatants were collected after centrifugation at $20,000 \mathrm{~g}$ at $4^{\circ} \mathrm{C}$ for $30 \mathrm{~min}$.

Radioimmunoassays of $I F$. Test tubes contained the following: $(a)$ $150 \mu \mathrm{l}$ of $0.1 \mathrm{M}$ Tris- $\mathrm{HCl}, \mathrm{pH} 8.0$, containing $0.15 \mathrm{M} \mathrm{NaCl}, 150 \mu \mathrm{g}$ of bovine serum albumin, and $50 \mathrm{pmol}$ of nonradioactive cobinamide; $(b)$ $300 \mu$ which consisted of various amounts of neutralized gastric juice and $0.01 \mathrm{M}$ Tris- $\mathrm{HCl}, \mathrm{pH} 8.0$, containing $0.15 \mathrm{M} \mathrm{NaCl}, 100 \mu \mathrm{g} / \mathrm{ml}$ of bovine serum albumin, and 0 to $3,000 \mathrm{fmol}$ of purified human IF; and (c) $100 \mu \mathrm{l}$ of rabbit anti-human IF serum diluted 1:500 in rabbit control serum or $100 \mu \mathrm{l}$ of rabbit anti-hog IF serum diluted 1:1,667 in rabbit control serum. After $22 \mathrm{~h}$ of gentle agitation at $4^{\circ} \mathrm{C}, 50 \mu \mathrm{l}$ of $0.01 \mathrm{M}$ Tris- $\mathrm{HCl}$; $\mathrm{pH} 8.0$, containing $0.15 \mathrm{M} \mathrm{NaCl}, 5 \mu \mathrm{g}$ of bovine serum albumin, and $35 \mathrm{pmol}$ of purified human IF- $\left.{ }^{57} \mathrm{Co}\right] \mathrm{Cbl}$ was added. After an additional $22 \mathrm{~h}$ of the agitation at $4^{\circ} \mathrm{C}, 500 \mu$ of saturated $\left(\mathrm{NH}_{4}\right)_{2} \mathrm{SO}_{4}$, adjusted to $\mathrm{pH} 8.0$ with Tris base, was added. After standing for $15 \mathrm{~min}$, the tubes were centrifuged at $15,000 \mathrm{~g}$ for $20 \mathrm{~min}$ and the entire supernatant liquid was assayed for ${ }^{57} \mathrm{Co}$. Under these conditions, $80-90 \%$ of the human IF- $\left[{ }^{57} \mathrm{Co}\right] \mathrm{Cbl}$ precipitated in the absence of unlabeled human IF. This value fell significantly and progressively to $20 \%$ as the amount of unlabeled human IF was increased from 10 to $2,000 \mathrm{fmol}$. No change was observed with the addition of 3,000 fmol of unlabeled human $R$ protein.

Assay of IF-Cbl binding to ileal mucosal homogenates. The binding of IF- $\left[{ }^{57} \mathrm{Co}\right] \mathrm{Cbl}$ to canine ileal mucosal homogenates was assayed as described previously (35), except that the homogenate pellets in the assays were collected by centrifugation at $20,000 \mathrm{~g}$ for $30 \mathrm{~min}$ at $4^{\circ} \mathrm{C}$ rather than by Millipore filtration. Assays were performed in Krebs-Ringer

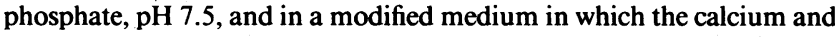
magnesium were replaced with $0.001 \mathrm{M} \mathrm{Na}_{2}$-EDTA. The difference between IF-Cbl bound to intestinal mucosal homogenates in these two media was termed the "EDTA inhibitable" fraction. The validity of using EDTA inhibitable binding as a measure of specific IF-Cbl binding to ileal mucosal IF-Cbl binding sites has been demonstrated previously $(27,35)$.

Studies concerning the adsorption of IF to Cbl-Sepharose. Test tubes contained $200 \mu \mathrm{l}$ of gastric juice and $25 \mu \mathrm{l}$ of $\mathrm{H}_{2} \mathrm{O}$ or $\mathrm{H}_{2} \mathrm{O}$ containing $20 \mathrm{nmol}$ of nonradioactive $\mathrm{Cbl}$ or cobinamide, and were incubated at $4^{\circ} \mathrm{C}$ for $1 \mathrm{~h}$. After the addition of $50 \mu \mathrm{l}$ of $\mathrm{H}_{2} \mathrm{O}$ containing $25 \mu \mathrm{l}$ (packed volume) of Sepharose or Cbl-Sepharose, the tubes were incubated at $4^{\circ} \mathrm{C}$ for an additional $16 \mathrm{~h}$. Albumin-coated charcoal, $200 \mu \mathrm{l}$, was added to adsorb any unbound $\mathrm{Cbl}$ or cobinamide and the tubes were centrifuged at $25,000 \mathrm{~g}$ for $20 \mathrm{~min}$ at $4^{\circ} \mathrm{C}$. $200 \mu \mathrm{l}$ of supernatant was then removed and assayed for immunoreactive IF, using rabbit antihog IF antibody as described above.

Studies concerning the stability of IF. Test tubes contained the following: (a) $75 \mu \mathrm{l}$ of $0.01 \mathrm{M}$ potassium phosphate, $\mathrm{pH} 7.5$, containing $0.15 \mathrm{M} \mathrm{NaCl}, 75 \mu \mathrm{g}$ bovine serum albumin, and $1.5 \mathrm{pmol}$ of nonradioactive cobinamide; (b) $20 \mu \mathrm{l}$ of $\mathrm{H}_{2} \mathrm{O}$ or $\mathrm{H}_{2} \mathrm{O}$ containing $15 \mathrm{fmol}$ of $\mathrm{CN}-\left[{ }^{57} \mathrm{Co}\right] \mathrm{Cbl}(200 \mu \mathrm{Ci} / \mathrm{nmol})$; and (c) $40 \mu \mathrm{l}$ of $0.1 \mathrm{M}$ Tris- $\mathrm{HCl}, \mathrm{pH} 8.6$, or the same solution with normal or patient gastric biopsy homogenate containing $12 \mathrm{fmol}$ of IF based on Cbl-binding ability. After incubating for $60 \mathrm{~min}$ at $4^{\circ} \mathrm{C}$ to allow Cbl-binding in those tubes that contained the $\mathrm{CN}-\left[{ }^{57} \mathrm{Co}\right] \mathrm{Cbl}$, the following additions were made: (d) $50 \mu \mathrm{l}$ of 0.1 $\mathrm{M} \mathrm{NaCl}$ (for $\mathrm{pH} 8$ studies), or $0.5 \mathrm{M}$ acetic acid (for $\mathrm{pH} 4$ studies), or $0.15 \mathrm{M} \mathrm{HCl}$ (for pH 2 studies); and $(e) 50 \mu$ of $\mathrm{H}_{2} \mathrm{O}$ or $\mathrm{H}_{2} \mathrm{O}$ containing $235 \mu \mathrm{g}$ of hog trypsin or $235 \mu \mathrm{g}$ of hog pepsin. The tubes were incubated for $10 \mathrm{~min}$ at $37^{\circ} \mathrm{C}$ and then for $5 \mathrm{~min}$ at $4^{\circ} \mathrm{C}$. Each tube then received ( $f$ ) $100 \mu \mathrm{l}$ of $\mathrm{H}_{2} \mathrm{O}$ containing sufficient Tris- $\mathrm{HCl}$, $\mathrm{pH} 10.0$, to bring the pH of each tube to 8.5; and $(\mathrm{g})$ either $20 \mu \mathrm{l}$ of $\mathrm{H}_{2} \mathrm{O}$ (for those tubes that received the $\mathrm{CN}-\left[{ }^{57} \mathrm{Co}\right] \mathrm{Cbl}$ before the first incubation), or $20 \mu \mathrm{l}$ of $\mathrm{H}_{2} \mathrm{O}$ containing $15 \mathrm{fmol}$ of $\mathrm{CN}-\left[{ }^{57} \mathrm{Co}\right] \mathrm{Cbl}$ (for those tubes that had not received $\mathrm{CN}-\left[{ }^{57} \mathrm{Co}\right] \mathrm{Cbl}$ before). After $60 \mathrm{~min}$ at $4^{\circ} \mathrm{C}$, each tube received $1 \mathrm{ml}$ of albumin-coated charcoal followed by centrifugation at $15,000 \mathrm{~g}$ for 30 min. The supernatant was collected and assayed for ${ }^{57} \mathrm{Co}$ to determine the amount of $\mathrm{CN}-\left[{ }^{57} \mathrm{Co}\right] \mathrm{Cbl}$ that was bound to IF.

Informed consent was obtained from normal subjects and patients, in accord with the Declaration of Helsinki, after approval by the Committee on Human Experimentation of the University of Colorado Health Sciences Center and the Louisiana State University Medical Center.

\section{Results}

Clinical presentation. As summarized in Table I, we have observed four patients who presented within the first few years of life with megaloblastic anemia due to an isolated lack of functional IF. Patients A, B, and C represent three of seven siblings in family I. Patient D is an only child in family II. The parents from both families, and the four remaining siblings from family I, are hematologically normal. This observation is expected, since IF is normally synthesized in vast excess and since the congenital absence or abnormality of IF is inherited as an autosomal recessive trait (22).

Analysis of IF in gastric juice. To determine whether patients A-D lacked IF in their gastric juice, or whether a functionally abnormal IF was present, we analyzed their gastric juice for Cblbinding ability due to IF. As shown in Table II, little, if any, Cbl-binding ability due to IF was detected in gastric juice from any of the four patients.

To determine if an abnormal IF with a decreased or absent ability to bind $\mathrm{Cbl}$ was present in the gastric juices, we also analyzed them for the presence of immunoreactive IF. Two different radioimmunoassays were employed, one of which utilized rabbit anti-human IF, and the second, rabbit anti-hog IF, which cross-reacts with human IF. Using purified human IF-[ $\left.{ }^{57} \mathrm{Co}\right] \mathrm{Cbl}$ as the labeled antigen and purified human IF devoid of $\mathrm{Cbl}$ as the unlabeled antigen, similar standard curves were obtained with both antisera, as shown in Fig. 1. As shown in Table II, the assay employing anti-human IF sera showed only trace amounts of immunoreactive material in the gastric juice of patients $A$, $B$, and $C$, while appreciable amounts of immunoreactive IF were observed using anti-hog IF sera. Neither assay detected any IF in normal saliva or saliva from patients A-C. The ratios of immunoreactive material in gastric juice as measured with the two assays, anti-human IF and anti-hog IF, ranged from 0.01 to 0.18 in patients $\mathrm{A}-\mathrm{C}$, and were much lower than the values observed with five normal subjects of 1.32 to 2.03 . The father 


\begin{tabular}{|c|c|c|c|c|c|c|c|c|c|c|}
\hline \multirow[b]{3}{*}{ Patient } & \multirow[b]{3}{*}{, A } & \multirow{3}{*}{$\begin{array}{l}\text { Age of onset of } \\
\text { megaloblastic anemia }\end{array}$} & & & \multirow{3}{*}{$\begin{array}{l}\text { Hematologic response } \\
\text { to parenteral } \mathrm{Cbl}\end{array}$} & \multirow{3}{*}{$\begin{array}{l}\text { Gastric } \\
\text { analysis* }\end{array}$} & \multirow{2}{*}{\multicolumn{2}{|c|}{ Gastric biopsy }} & \multicolumn{2}{|c|}{$\begin{array}{l}\text { Serum auto } \\
\text { antibodies }\end{array}$} \\
\hline & & & \multicolumn{2}{|c|}{ Schilling test } & & & & & \multirow[b]{2}{*}{ IF } & \multirow{2}{*}{$\begin{array}{l}\text { Parietal } \\
\text { cell }\end{array}$} \\
\hline & & & $-\mathrm{IF}$ & $+\mathrm{IF}$ & & & Light & EM & & \\
\hline & $y r$ & $y r$ & $\%$ & $\%$ & & & & & & \\
\hline \multicolumn{11}{|l|}{ Family Ił } \\
\hline Patient A & 15 & $1-2 / 3$ & $<1$ & 15 & Complete & Normal & Normal & Normal & No & No \\
\hline Patient B & 13 & 2 & $<1$ & 12 & Complete & Normal & Normal & NS" & No & No \\
\hline Patient C & 10 & $1-1 / 2$ & $<1$ & 5 & Complete & Normal & Normal & NS" & No & No \\
\hline \multicolumn{11}{|l|}{ Family II§ } \\
\hline Patient D & 4 & 4 & $<1$ & 6 & Complete & Normal & Normal & Normal & No & No \\
\hline
\end{tabular}

* Based on volume and acid output after stimulation with pentagastrin. $¥$ The mother, father, and four additional siblings were normal hematologically. $\S$ The mother and father were normal hematologically. "Not studied.

from family I had a ratio of 1.40 , while the ratios for the mother and a hematologically normal sibling from family I were moderately reduced, with values of 0.94 and 1.04 , respectively. These observations suggested that patients A, B, and C lacked normal IF in their gastric juices and that an abnormal IF was present that had a markedly decreased or absent ability to bind $\mathrm{Cbl}$. This abnormal IF appeared to lack most of the antigenic determinants recognized by the anti-human IF sera while retaining at least many of the antigenic determinants recognized by the anti-hog IF sera. These observations also suggested that gastric juice from the father of family I contained only normal IF, and that gastric juice from the mother and the hematologically normal sibling from family I contained a mixture of normal and the abnormal IF. No immunoreactive IF was detected in the gastric juice of patient D from family II, suggesting that this patient has a complete lack of normal or abnormal IF.

When freshly aspirated and unneutralized normal gastric juice was incubated at $37^{\circ} \mathrm{C}$ in the absence of $\mathrm{Cbl}$, a form of IF similar to that of patients A-C was detected, as shown in Fig. 2 $A$, since Cbl-binding ability due to IF and anti-human IF im-

Table II. Intrinsic Factor Levels Obtained in Gastric Juice with a Cobalamin-binding Assay and Immunoassays Using Two Different Antisera

\begin{tabular}{|c|c|c|c|c|c|c|}
\hline \multirow[b]{2}{*}{ Gastric juice* } & \multicolumn{3}{|c|}{ Cbl-binding ability } & \multicolumn{3}{|c|}{ Immunoreactive IF } \\
\hline & Total & IF $\neq$ & & Anti-human IF $\S$ & Anti-hog IF" & $\begin{array}{l}\text { Anti-human IF/ } \\
\text { anti-hog IF }\end{array}$ \\
\hline & $\mathrm{pmol} / \mathrm{ml}$ & $\mathrm{pmol} / \mathrm{ml}$ & $\%$ & $\mathrm{pmol} / \mathrm{ml}$ & $\mathrm{pmol} / \mathrm{ml}$ & \\
\hline Normals $(n=5)$ & $15.1-39.7$ & $10.0-34.4$ & $66-98$ & $17.3-66.4$ & $10.9-32.7$ & $1.32-2.03$ \\
\hline \multicolumn{7}{|l|}{ Family I } \\
\hline Father & 19.7 & 14.5 & 74 & 33.9 & 24.3 & 1.40 \\
\hline Mother & 46.9 & 36.2 & 77 & 69.3 & 73.8 & 0.94 \\
\hline Sibling & 70.1 & 58.9 & 84 & 109.4 & 105.7 & 1.04 \\
\hline Patient A & 8.3 & 1.5 & 18 & 0.2 & 11.7 & 0.02 \\
\hline Patient B & 37.9 & 1.8 & 5 & 1.2 & 10.1 & 0.12 \\
\hline Patient C & 15.4 & 2.2 & 14 & 0.1 & 12.9 & 0.01 \\
\hline Patient C (basal) & 70.8 & 0.8 & 1 & 0.7 & 3.8 & 0.18 \\
\hline Patient C (stimulated) & 34.1 & 0.9 & 3 & 0.6 & 10.0 & 0.06 \\
\hline \multicolumn{7}{|l|}{ Family II } \\
\hline Patient D & 15.6 & 0.3 & 2 & $<0.1$ & $<0.1$ & - \\
\hline Patient D (basal) & 102.0 & 1.8 & 2 & $<0.1$ & $<0.1$ & - \\
\hline Patient D (stimulated) & 34.6 & 1.8 & 5 & $<0.1$ & $<0.1$ & - \\
\hline
\end{tabular}

\footnotetext{
* Except where indicated, gastric juice samples were aspirated 30 min after stimulation with pentagastrin and contained both basal and stimulated gastric juice. $¥$ The amount of Cbl-binding ability measured in the presence of a 100 -fold excess of nonradioactive cobinamide, which inhibits the binding of $\left[{ }^{57} \mathrm{Co}\right] \mathrm{Cbl}$ to $\mathrm{R}$ protein, but not to IF. $\S$ The antibody used in the immunoassay was rabbit anti-human IF. Human IF-[ $\left.{ }^{57} \mathrm{Co}\right] \mathrm{Cbl}$ was the radioactive ligand, and purified human IF-Cbl was used to obtain the standard curve. "The antibody used in the immunoassay was rabbit anti-hog IF which cross-reacts with human IF. Human IF-[ $\left.{ }^{57} \mathrm{Co}\right] \mathrm{Cbl}$ was the radioactive ligand, and purified human IF-Cbl was used to obtain the standard curve.
} 


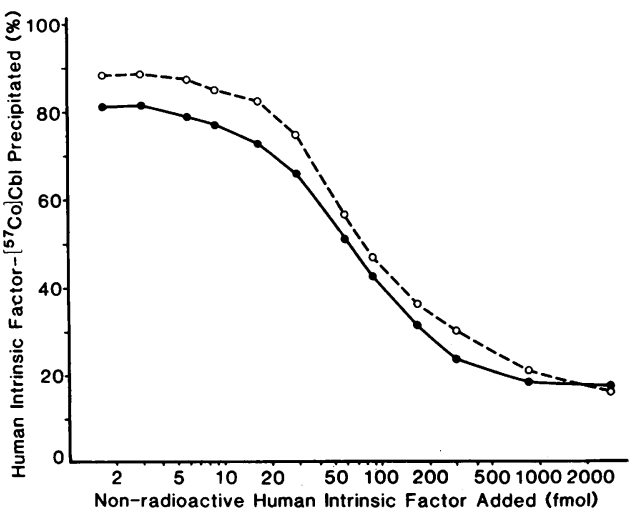

Figure 1. Standard curves obtained with the radioimmunoassays for human IF. The two assays were identical except for the nature of the antisera. ๑, rabbit anti-human IF; $\bigcirc$, rabbit anti-hog IF.

munoreactive material decreased at the same rate, while antihog IF immunoreactive material decreased at a much lower rate. This observation suggests that normal human IF is altered slowly in normal acid gastric juice, with a concurrent loss of Cbl-binding ability and antigenic determinants recognized by the anti-human IF sera. It also suggests that the loss of antigenic determinants recognized by the anti-hog IF sera proceeds at a much slower rate. Patients $\mathrm{A}, \mathrm{B}$, and $\mathrm{C}$ might therefore possess an abnormal IF that is much more susceptible to such alterations, such that they occur within minutes of the secretion of IF into gastric juice, rather than within hours as occurs with normal IF.

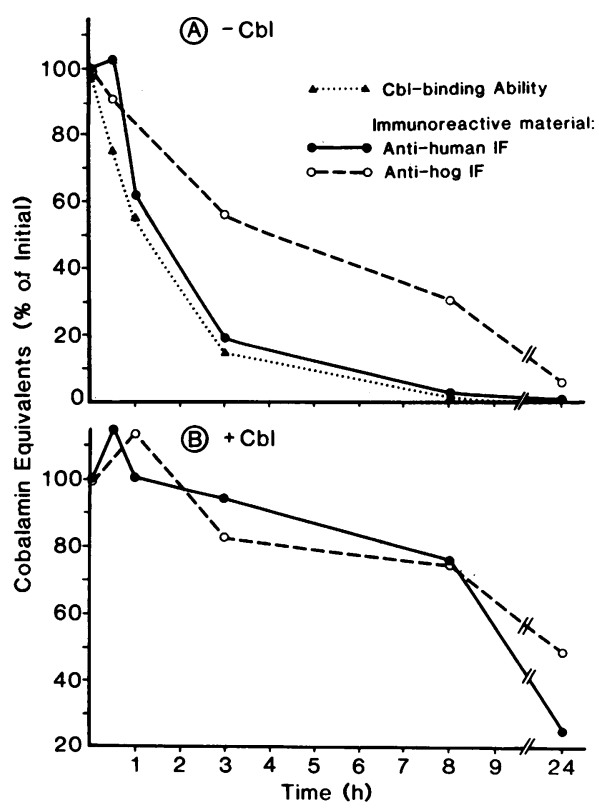

Figure 2. Changes in IF in freshly aspirated normal human gastric juice that was incubated at $37^{\circ} \mathrm{C}$ in: $(A)$ the absence of added $\mathrm{Cbl}$ and $(B)$ the presence of a large excess of nonradioactive $\mathrm{Cbl}, 450 \mathrm{pmol} / \mathrm{ml}$, to saturate all of the Cbl-binding protein in the gastric juice. At various times, aliquots were removed, adjusted to $\mathrm{pH} 8$ with $0.2 \mathrm{M}$ Tris base, and assayed for IF based on its Cbl-binding ability and based on its immunoreactivity with the two radioimmunoassays. The $\mathrm{pH}$ of the gastric juice was 2.5 and it contained $35 \mathrm{pmol} / \mathrm{ml}$ of Cbl-binding ability due to IF before incubation.
We further analyzed the various gastric juices by subjecting them to gel filtration, as shown in Fig. 3. IF in normal neutralized gastric juice eluted with an apparent molecular weight of 70,000 based on radioimmunoassays employing both the anti-human IF and the anti-hog IF sera (Fig. $3 A$ ). With freshly neutralized gastric juice from patient $A$, essentially no IF was detected using the anti-human IF sera, while immunoreactive IF with an apparent molecular weight of $\sim 40,000$ was detected using the antihog IF sera (Fig. 3 B). Freshly neutralized gastric juice from the father of family I showed a normal elution pattern (Fig. $3 C$ ), while freshly neutralized gastric juice from the mother of family I gave a pattern (Fig. $3 \mathrm{D}$ ) indicating the presence of both normal IF and the small molecular weight IF recognized only by the anti-hog IF sera that was seen with patient A. With normal unneutralized gastric juice that had been incubated at $37^{\circ} \mathrm{C}$ for $8 \mathrm{~h}$ in the presence of a saturating amount of $\mathrm{Cbl}$, immunoreactive IF was detected with both antisera, although the molecular weight in both cases was $\sim 55,000$, suggesting that some minor alterations of the IF had occurred (Fig. $3 E$ ). With normal unneutralized gastric juice that had been incubated at $37^{\circ} \mathrm{C}$ for $8 \mathrm{~h}$ in the absence of $\mathrm{Cbl}$, however, the IF appeared virtually identical to that observed with patient A: only small amounts of material were detected with the anti-human IF sera, while significant amounts of material with an apparent molecular weight of $\sim 40,000$ were detected with the anti-hog IF sera (Fig. $3 \mathrm{~F}$ ).

To determine whether the patients' abnormal IF had lost the $\mathrm{Cbl}$-binding site entirely, or if it still retained all or a portion of the Cbl-binding site but with a markedly decreased affinity for $\mathrm{Cbl}$, we studied the ability of normal IF and the abnormal IF to bind to Cbl-Sepharose. As shown in Table III, IF from two normal subjects and the abnormal IF from patients $A$ and $C$ did bind to Cbl-Sepharose. In all cases, binding to Cbl-Sepharose was blocked by a prior incubation with a 1,000-fold excess of Cbl. Binding was also blocked to a small extent by prior incubation with a 1,000-fold excess of cobinamide, a Cbl analogue that has a markedly reduced but not absent affinity for human IF. These results, together with the Cbl-binding studies presented in Table II that were performed with only a 10-fold excess of $\left[{ }^{57} \mathrm{Co}\right] \mathrm{Cbl}$, indicate that the abnormal IF retains at least a portion of the Cbl-binding site, although its affinity for $\mathrm{Cbl}$ is markedly reduced.

Studies with gastric biopsies. IF was assayed in homogenates of gastric biopsies obtained from patient A of family I and patient D of family II. The results are shown in Table IV. Significant, although somewhat reduced, amounts of IF were present in the gastric biopsy of patient $\mathrm{A}$ based on Cbl-binding ability and both RIAs that utilized anti-human IF and anti-hog IF antisera. These results suggested that the IF present in the gastric biopsy of patient A differed from the IF present in the gastric juice of patient $A$ (compare Table II and Table IV). These observations also supported the suggestion (see above) that the abnormal IF in family I was altered sometime between its synthesis and within minutes after its secretion in the gastric juice. The results obtained with patient D of family II indicated a complete lack of IF based on assays of Cbl-binding ability and both RIAs, providing further evidence that this patient has a complete lack of IF rather than an abnormal IF.

Immunohistochemical electron microscopic studies failed to detect IF in the gastric biopsy of patient D, family II, using either anti-human IF sera (not shown) or anti-hog IF sera (Fig. $4 A$ ). IF was identified in the gastric biopsy of patient $\mathrm{A}$, family 


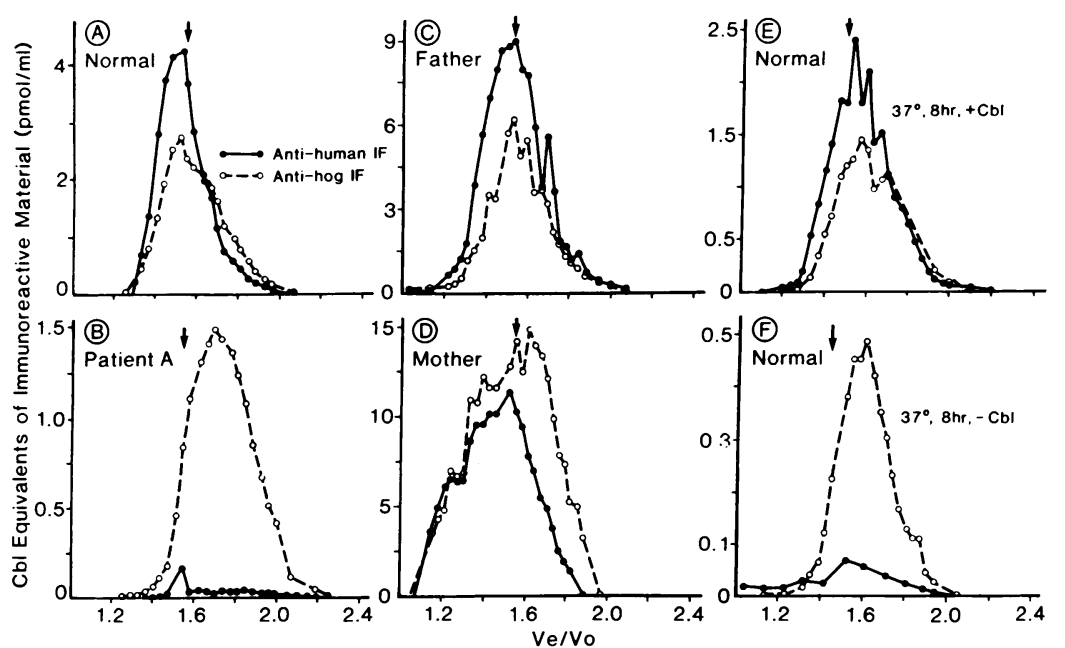

Figure 3. Gel filtration of gastric juice and the subsequent assay of IF with the radioimmunoassay using rabbit anti-human IF and the radioimmunoassay using rabbit anti-hog IF. Samples A-C contained $2.0 \mathrm{ml}$ of freshly neutralized gastric juice from: $(A)$ a normal subject; $(B)$ patient A from family $\mathrm{I} ;(C)$ father of family I. Sample D contained $4.0 \mathrm{ml}$ of freshly neutralized gastric juice from the mother of family I. Samples E and $\mathrm{F}$ contained $0.75 \mathrm{ml}$ obtained from the normal gastric juice that had been incubated at $37^{\circ} \mathrm{C}$ for $8 \mathrm{~h}$ before neutralization and were obtained from the experiment shown in Fig. $2 B$ and $A$, respectively. All samples also contained $30 \mathrm{fmol}$ of normal human IF$\left[{ }^{57} \mathrm{Co}\right] \mathrm{Cbl}$, whose value for $\mathrm{Ve}$ is indicated by the closed arrow ( 1 ) in each panel, and $1.5 \mathrm{mg}$ of Blue dextran, which was used to obtain values for Vo. Gel filtration was performed at $4^{\circ} \mathrm{C}$ on $1.5 \times 60 \mathrm{~cm}$ columns of Sephadex G-150 equilibrated with $0.01 \mathrm{M}$ Tris- $\mathrm{HCl}, \mathrm{pH} 8.0$, containing $0.15 \mathrm{M} \mathrm{NaCl}$ and 100 $\mu \mathrm{g} / \mathrm{ml}$ bovine serum albumin.
I, in the same normal locations, i.e., perinuclear membrane, rough endoplasmic reticulum, Golgi apparatus, tubulovesicles, and membranes of the multivesicular body of parietal cells, using either the anti-human IF sera (not shown) or the anti-hog IF sera (Fig. $4 \mathrm{~B}$ ). Gastric biopsies obtained after pentagastrin stimulation demonstrated normal translocation of the IF on tubulovesicles to the canalicular surface membrane.

Table III. Adsorption of IF to Sepharose, and to Cbl-Sepharose in the Absence and Presence of $\mathrm{Cbl}$ and Cobinamide

\begin{tabular}{|c|c|c|c|c|c|c|}
\hline \multirow{3}{*}{$\begin{array}{l}\text { Gastric } \\
\text { juice }\end{array}$} & \multicolumn{4}{|c|}{ Additions* } & & \\
\hline & \multirow[t]{2}{*}{$\mathrm{Cbl}$} & \multirow[t]{2}{*}{ Cobinamide } & \multirow[t]{2}{*}{$\begin{array}{l}\text { Cbl- } \\
\text { Sepharose }\end{array}$} & \multirow[t]{2}{*}{ Sepharose } & \multicolumn{2}{|c|}{$\begin{array}{l}\text { Immunoreactive IF } \\
\text { in supernatant }\end{array}$} \\
\hline & & & & & $\mathrm{pmol} / \mathrm{ml}$ & $\%$ \\
\hline \multicolumn{7}{|c|}{ Normal 1} \\
\hline 1 & - & - & - & - & 32.9 & $(100)$ \\
\hline 2 & - & - & + & - & 1.4 & 4 \\
\hline 3 & + & - & + & - & 52.7 & 160 \\
\hline 4 & - & + & + & - & 7.1 & 22 \\
\hline \multicolumn{7}{|c|}{ Normal 2} \\
\hline 1 & - & - & - & + & 30.6 & $(100)$ \\
\hline 2 & - & - & + & - & 0.1 & $<1$ \\
\hline 3 & + & - & + & - & 61.1 & 200 \\
\hline 4 & - & + & + & - & 8.9 & 29 \\
\hline \multicolumn{7}{|c|}{ Patient A } \\
\hline 1 & - & - & - & + & 13.2 & $(100)$ \\
\hline 2 & - & - & + & - & 0.7 & 5 \\
\hline 3 & + & - & + & - & 24.6 & 186 \\
\hline 4 & - & + & + & - & 5.2 & 39 \\
\hline \multicolumn{7}{|c|}{ Patient C } \\
\hline 1 & - & - & - & + & 13.2 & $(100)$ \\
\hline 2 & - & - & + & - & 0.7 & 5 \\
\hline 3 & + & - & + & - & 22.7 & 172 \\
\hline 4 & - & + & + & - & 5.6 & 42 \\
\hline
\end{tabular}

Gastric juice samples were incubated under various conditions at $4^{\circ} \mathrm{C}$, as described under Methods, and the supernatants were then assayed for immunoreactive IF using anti-hog IF antisera.

* A 1-h incubation was performed after the addition of $\mathrm{Cbl}$ or cobinamide and a 16-h incubation was performed after the addition of Sepharose or Cbl-Sepharose.
As shown in Fig. $5 C$, the IF present in the gastric biopsy of patient $\mathrm{A}$ appeared to bind $\mathrm{Cbl}$ normally and had a normal apparent molecular weight $(66,000)$ when it was incubated with a twofold excess of $\left[{ }^{57} \mathrm{Co}\right] \mathrm{Cbl}$ and subjected to gel filtration. The elution profile was indistinguishable from that observed with IF obtained with a gastric biopsy of a normal subject (Fig. 5 D). This result differed from that obtained with IF from the gastric juice of patient $\mathrm{A}$, since only a small peak of $\left[{ }^{57} \mathrm{Co}\right] \mathrm{Cbl}$ was observed in the 66,000-mol-wt position with basal gastric juice (Fig. $5 \mathrm{~A}$ ) and no $\left[{ }^{57} \mathrm{Co}\right] \mathrm{Cbl}$ was observed in this position with stimulated gastric juice of patient A (Fig. 5 B).

As shown in Fig. 6, IF from the gastric biopsy of patient A facilitated the specific binding of $\left[{ }^{57} \mathrm{Co}\right] \mathrm{Cbl}$ to ileal homogenates in a manner that was indistinguishable from that of IF obtained from either a gastric biopsy of a normal subject or a gastric juice of a normal subject. In contrast, IF from the gastric juice of patient A did not facilitate the specific binding of $\left[{ }^{57} \mathrm{Co}\right] \mathrm{Cbl}$ to ileal homogenates.

As shown in Table V, IF obtained from the gastric biopsy of a normal subject was stable, based on retention of its $\mathrm{Cbl}$ binding ability and on its retention of bound $\mathrm{Cbl}$ when it was incubated at $37^{\circ} \mathrm{C}$ at various pHs in the absence and presence of pepsin or trypsin. In contrast, IF obtained from the gastric biopsy of patient $A$ was unstable and suffered a reduction in Cbl-binding ability when incubated with trypsin at $\mathrm{pH} 8$, with pepsin at $\mathrm{pH} \mathrm{4}$, or in the presence or absence of pepsin at $\mathrm{pH}$ 2. Prior incubation with a twofold excess of $\left[{ }^{57} \mathrm{Co}\right] \mathrm{Cbl}$ markedly stabilized the IF from patient $\mathrm{A}$, based on the retention of bound $\left[{ }^{57} \mathrm{Co}\right] \mathrm{Cbl}$ at $\mathrm{pH} 8$ with trypsin and at $\mathrm{pH} 4$ with pepsin, but provided only slight stabilization at $\mathrm{pH} 2$ in the presence or absence of pepsin.

Improved $\mathrm{Cbl}$ absorption via stabilization of $\mathrm{IF}$. The results of standard Schilling tests performed on patients A, B, and C indicated negligible absorption of $\left[{ }^{57} \mathrm{Co}\right] \mathrm{Cbl}$, as shown in Table VI, with a mean value of $0.6 \%$ of the orally administered $\left[{ }^{57} \mathrm{Co}\right] \mathrm{Cbl}$ being present in $24-\mathrm{h}$ urines. Schilling tests were also performed with the addition of bicarbonate to partially neutralize the patients' gastric juice, and with the addition of nonradioactive cobinamide to block the patients' $R$ protein and allow the $\left[{ }^{57} \mathrm{Co}\right] \mathrm{Cbl}$ to become bound to IF in the patients' gastric juice, rather than to $\mathrm{R}$ protein, as would otherwise occur. Under these 
Table IV. Intrinsic Factor Levels Obtained in Homogenates of Gastric Biopsies with a Cobalamin-binding Assay and Immunoassays Using Two Different Antisera

\begin{tabular}{|c|c|c|c|c|c|c|}
\hline \multirow[b]{3}{*}{ Gastric biopsy } & \multirow{2}{*}{\multicolumn{2}{|c|}{ Cbl-binding ability* }} & & \multicolumn{3}{|c|}{ Immunoreactive IF* } \\
\hline & & & & \multirow[b]{2}{*}{ Anti-human IF§ } & \multirow[b]{2}{*}{ Anti-hog IF" } & \multirow{2}{*}{$\begin{array}{l}\text { Anti-human IF/ } \\
\text { anti-hog IF }\end{array}$} \\
\hline & Total & IF $\ddagger$ & & & & \\
\hline & $\mathrm{pmol} / 100 \mathrm{mg}$ & $\mathrm{pmol} / 100 \mathrm{mg}$ & $\%$ & $\mathrm{pmol} / 100 \mathrm{mg}$ & $\mathrm{pmol} / 100 \mathrm{mg}$ & \\
\hline Normals (2) & $1.9,3.9$ & $1.3,3.8$ & 68,97 & $6.3,13.5$ & $2.7,6.9$ & $2.23,1.96$ \\
\hline \multicolumn{7}{|l|}{ Family I } \\
\hline Patient A & 1.1 & 0.5 & 45 & 1.4 & 1.0 & 1.40 \\
\hline \multicolumn{7}{|l|}{ Family II } \\
\hline Patient D & 1.2 & $<0.1$ & $<8$ & $<0.1$ & $<0.1$ & - \\
\hline
\end{tabular}

* The values are expressed as picomoles per 100 milligrams wet weight of tissue. $¥$ The amount of Cbl-binding ability measured in the presence of a 100 -fold excess of nonradioactive cobinamide, which inhibits the binding of $\left[{ }^{57} \mathrm{Co}\right] \mathrm{Cbl}$ to $\mathrm{R}$ protein, but not to IF. $\S$ The antibody used in the immunoassay was rabbit anti-human IF. Human IF- $\left[{ }^{57} \mathrm{Co}\right] \mathrm{Cbl}$ was the radioactive ligand, and purified human IF-Cbl was used to obtain the standard curve. "The antibody used in the immunoassay was rabbit anti-hog IF, which cross-reacts with human IF. Human IF- $\left[{ }^{57} \mathrm{Co}\right] \mathrm{Cbl}$ was the radioactive ligand, and purified human IF-Cbl was used to obtain the standard curve.

conditions, which were chosen to stabilize the patients' IF based on the data in Table VI, the absorption of Cbl markedly increased with a mean value of $4.2 \%$ of the orally administered $\left[{ }^{57} \mathrm{Co}\right] \mathrm{Cbl}$ being present in the 24-h urines. This observation indicates that the abnormal IF in family I has the ability to facilitate $\mathrm{Cbl} \mathrm{ab-}$ sorption in vivo if it can be protected from the deleterious effects of acid and proteolytic enzymes.

\section{Discussion}

We have observed three siblings (patients $\mathrm{A}, \mathrm{B}$, and $\mathrm{C}$ from family I) who developed megaloblastic anemia within the first two years of life due to cobalamin malabsorption secondary to a lack of functional IF in their gastric juice. We have shown that IF is present in their parietal cells and that this IF is normal in terms of the following parameters: $(a)$ Cbl-binding ability; $(b)$ an apparent molecular weight of 66,000 as its IF- $\left[{ }^{57} \mathrm{Co}\right] \mathrm{Cbl}$ complex based on gel filtration; $(c)$ the ability to facilitate the binding of $\mathrm{Cbl}$ to ileal receptors; $(d)$ its reaction with rabbit anti-human IF sera in an RIA; and (e) its reaction with rabbit anti-hog IF in an RIA.
This IF appears to be abnormal, however, in the gastric juice of these patients since it differs from normal IF in the following parameters: (a) a marked decrease (but not absent) affinity for $\mathrm{Cbl}$; $(b)$ an apparent molecular weight of 40,000 based on gel filtration; (c) a markedly decreased or absent ability to facilitate the binding of $\mathrm{Cbl}$ to ileal receptors; and $(d)$ a markedly decreased or absent ability to react with rabbit anti-human IF sera in an RIA.

The defect in these patients is not due to an inability of parietal cells to secrete IF since the intracellular IF translocates normally to the canalicular surface and the patients' gastric juices contain IF that reacts with rabbit anti-hog IF sera in an RIA. The fact that the patients' IF has an apparent molecular weight of only 40,000 based on gel filtration and the RIA using antihog IF sera indicates that the patients' IF is partially degraded within minutes after being secreted into gastric juice. A similar phenomenon also appears to occur with normal IF in normal gastric juice, although hours rather than minutes are required for the partial degradation to occur.

These observations suggest that the IF present in the patients' parietal cells has an abnormal structure that renders it more
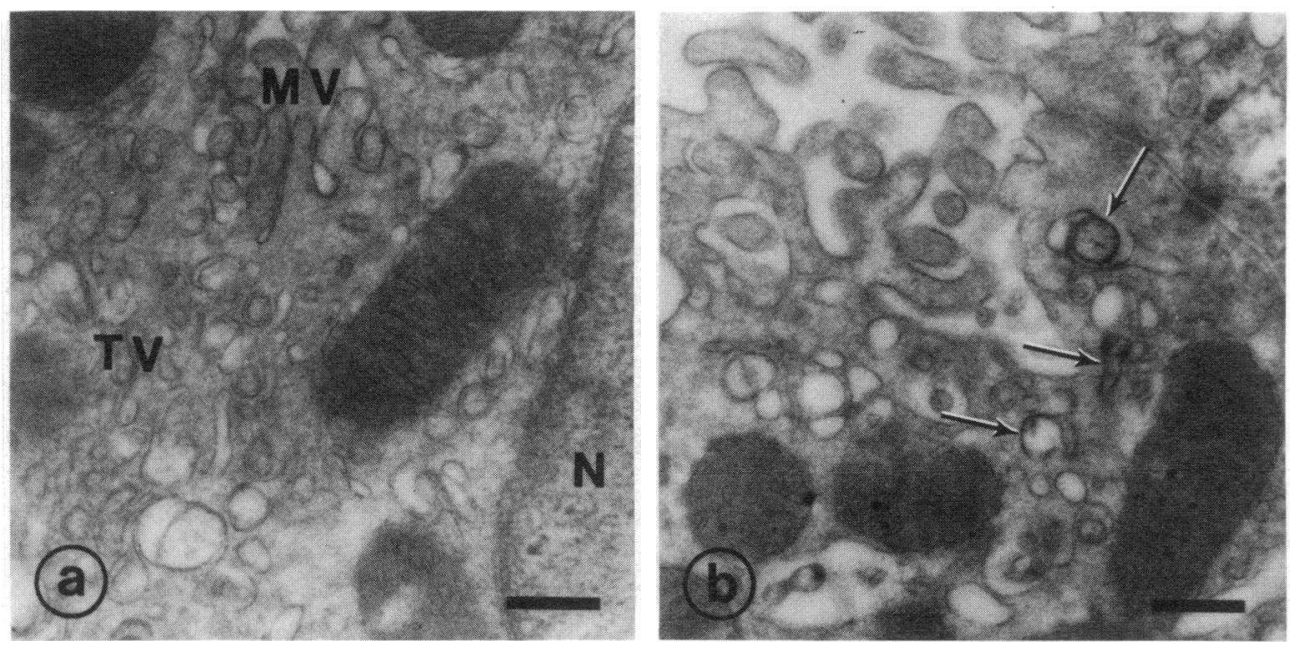

Figure 4. Immunohistochemical electron microscopic assay of IF in parietal cells of gastric biopsies using rabbit anti-hog IF sera. $(A)$ Patient D of family II. (B) Patient $A$ of Family $I$. The arrows $(\rightarrow)$ indicate the presence of IF on tubulovesicles. 


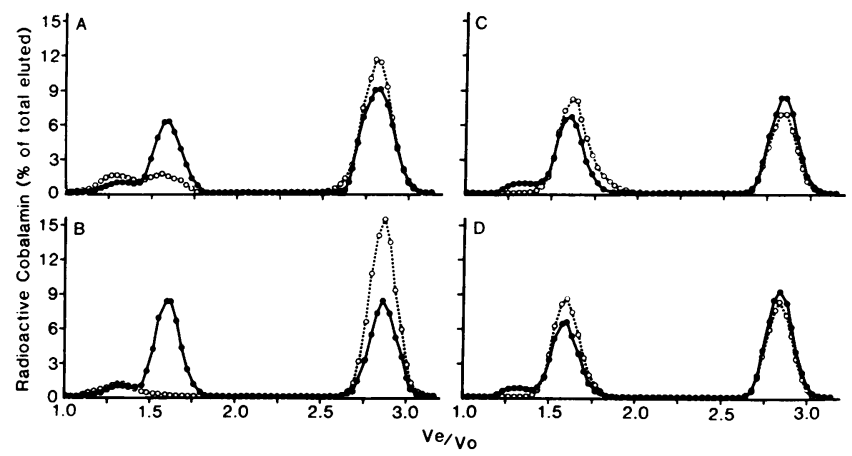

Figure 5. Gel filtration of IF-Cbl in gastric juice and gastric biopsies. In all panels, $\bullet$ represents the elution of $30 \mathrm{pmol}$ of $\left[{ }^{58} \mathrm{Co}\right] \mathrm{Cbl}$ that was mixed with $3,000 \mathrm{pmol}$ of cobinamide and incubated in a volume of $0.5 \mathrm{ml}$ for $1 \mathrm{~h}$ at $22^{\circ} \mathrm{C}$ with $10 \mathrm{pmol}$ of $\mathrm{IF}$ obtained from normal gastric juice. $O$ represents the elution of $200 \mathrm{fmol}$ of $\left[{ }^{57} \mathrm{Co}\right] \mathrm{Cbl}$ that was mixed with $2,000 \mathrm{fmol}$ of cobinamide and incubated in a volume of 1 $\mathrm{ml}$ at room temperature for $1 \mathrm{~h}$ with $100 \mathrm{fmol}$ of IF obtained from: $(A)$ basal gastric juice of patient $\mathrm{A} ;(B)$ stimulated gastric juice of patient $\mathrm{A} ;(C)$ gastric biopsy of patient $\mathrm{A}$; and $(D)$ gastric biopsy of a normal subject. The samples containing the $\left[{ }^{58} \mathrm{Co}\right] \mathrm{Cbl}$ and $\left[{ }^{57} \mathrm{Co}\right] \mathrm{Cbl}$ were chilled to $4^{\circ} \mathrm{C}$ and mixed together immediately before gel filtration. Samples also contained $5 \mathrm{mg}$ of Blue dextran, which was used to determine the value of Vo. Sample incubations and gel filtration on 2 $\times 90 \mathrm{~cm}$ columns of Sephadex G-150 were performed in $0.01 \mathrm{M}$ Tris$\mathrm{HCl}, \mathrm{pH} 8$, containing $0.75 \mathrm{M} \mathrm{NaCl}$ and $50 \mu \mathrm{g} / \mathrm{ml}$ of bovine serum albumin.

susceptible to partial degradation in gastric juice. This concept is supported by the fact that patient A's IF present in his gastric biopsy suffered a marked loss in Cbl-binding ability when it was incubated at acid $\mathrm{pH}$, particularly in the presence of pepsin.

It is possible that these patients possess a structurally normal IF in their parietal cells and that gastric biopsies and/or gastric juice possess a structurally abnormal proteolytic enzyme, such as a structurally abnormal pepsin, that is able to partially degrade IF at an abnormally increased rate. This possibility appears unlikely, however, since the patients' mother and another sibling

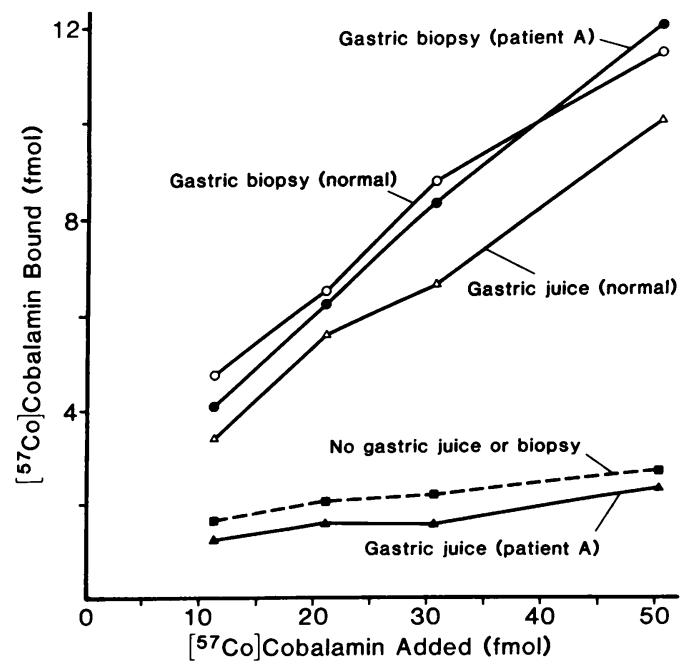

Figure 6. Ability of IF from various sources to facilitate the specific binding of $\left[{ }^{57} \mathrm{Co}\right] \mathrm{Cbl}$ to canine ileal mucosal homogenates. All samples contained $75 \mathrm{fmol}$ of IF based on the radioimmunoassay with rabbit anti-hog IF.
Table V. Stability of IF Present in Gastric Biopsies Obtained from a Normal Subject and Patient $A$ when Exposed to Various pHs and Proteolytic Enzymes as Described under Methods

\begin{tabular}{|c|c|c|c|c|c|c|}
\hline \multirow{4}{*}{$\begin{array}{l}\mathrm{pH} \text { of } \\
10 \text {-min } \\
\text { incubation } \\
\text { at } 37^{\circ} \mathrm{C}\end{array}$} & \multirow[b]{4}{*}{ Additions } & \multirow{4}{*}{$\begin{array}{l}\text { Final } \\
\mathrm{pH}\end{array}$} & \multicolumn{4}{|c|}{$\begin{array}{l}\left.\mathrm{CN}-{ }^{57} \mathrm{Co}\right] \mathrm{Cbl} \text { bound to IF } \\
\text { after final incubation }\end{array}$} \\
\hline & & & \multicolumn{2}{|c|}{ Normal } & \multicolumn{2}{|c|}{ Patient A } \\
\hline & & & \multicolumn{2}{|c|}{$\begin{array}{l}\text { Presence of } \mathrm{CN} \text { - } \\
\left.{ }^{57} \mathrm{Co}\right] \mathrm{Cbl} \text { during } \\
10-\text { min incuba- } \\
\text { tion at } 37^{\circ} \mathrm{C}\end{array}$} & \multicolumn{2}{|c|}{$\begin{array}{l}\text { Presence of } \mathrm{CN}- \\
{\left[{ }^{57} \mathrm{Co}\right] \mathrm{Cbl} \text { during }} \\
10 \text {-min incuba- } \\
\text { tion at } 37^{\circ} \mathrm{C}\end{array}$} \\
\hline & & & $-*$ & $+\ddagger$ & $-*$ & $+\ddagger$ \\
\hline & & & $\%$ & $\%$ & $\%$ & $\%$ \\
\hline 8 & - & 8 & $(100)$ & $(100)$ & $(100)$ & (100) \\
\hline 8 & Pepsin & 8 & 96 & 109 & 95 & 102 \\
\hline 8 & Trypsin & 8 & 104 & 115 & 47 & 101 \\
\hline 4 & - & 8 & 85 & 102 & 87 & 105 \\
\hline 4 & Pepsin & 8 & 95 & 107 & 49 & 102 \\
\hline 2 & - & 8 & 101 & 100 & 7 & 21 \\
\hline 2 & Pepsin & 8 & 86 & 86 & 8 & 17 \\
\hline
\end{tabular}

* The $\left[{ }^{57} \mathrm{Co}\right] \mathrm{Cbl}$ was not added until after the IF was incubated for $10 \mathrm{~min}$ at $37^{\circ} \mathrm{C}$ at the indicated $\mathrm{pH}$ in the presence of the indicated proteolytic enzymes and until after all samples had been adjusted to a final $\mathrm{pH}$ of 8 .

$\ddagger$ The $\left[{ }^{57} \mathrm{Co}\right] \mathrm{Cbl}$ was added before the 10 - $\mathrm{min}$ incubation at $37^{\circ} \mathrm{C}$.

have gastric juice that contains both normal and partially degraded IF in approximately equal amounts and since neither the mother nor this sibling has ever developed signs of $\mathrm{Cbl}$ deficiency.

These findings are thus more consistent with the concept that the mother and the unaffected sibling possess one gene for structurally normal IF and a second gene for the structurally abnormal IF. Gastric juice from the patient's unaffected father contains only normal IF; it is likely that he contains one gene for structurally normal IF and a second gene that is "silent" in the sense that it does not code for an IF that is synthesized in

Table VI. Effect of Stabilizing IF with

Bicarbonate and Cobinamide on the Results of Schilling Tests Performed on Patients $A, B$, and $C$

\begin{tabular}{lll}
\hline Subject* & Standard & $\begin{array}{l}+\mathrm{NaHCO}_{3} \\
+ \text { Cobinamide§ }\end{array}$ \\
\hline Patient A & 0.4 & $\%$ \\
Patient B & 0.5 & 2.7 \\
Patient C & $\underline{1.0}$ & 5.7 \\
Mean & 0.6 & $\frac{4.3}{4.2^{\prime \prime}}$
\end{tabular}

* Patients $\mathrm{A}$ and $\mathrm{C}$ undertook the two Schilling tests in the order indicated with a 1-wk interval in between. The reverse order with the same interval was utilized with Patient $B$.

$\ddagger$ Performed with $0.2 \mathrm{nmol}$ of $\mathrm{CN}-\left[{ }^{57} \mathrm{Co}\right] \mathrm{Cbl}$. $\S$ Performed the same as the standard Schilling test, except that $2.4 \mathrm{~g}$ of $\mathrm{NaHCO}_{3}$ was given orally $1 \mathrm{~min}$ before the solution of $\mathrm{CN}$ $\left[{ }^{57} \mathrm{Co}\right] \mathrm{Cbl}$ that contained $200 \mathrm{nmol}$ of nonradioactive cobinamide. " $P<0.05$ compared with the mean value obtained with the standard Schilling test. 
parietal cells and secreted into gastric juice. Because of the marked variations in the concentration of IF in normal gastric juice, it was not possible to demonstrate this directly. Defects that result in a lack of IF synthesis in parietal cells clearly appear to exist, however, since patient D from family II had no detectable IF in his gastric juice or in his parietal cells, as judged by a variety of assays for IF performed on his gastric biopsies.

Our studies thus support the concept that the three patients from family I inherited a gene for absent IF from their father and a gene for a structurally abnormal IF from their mother, who, together with a clinically unaffected sibling, appears to possess one gene for a structurally normal IF and one gene for the abnormal IF. The fact that the father, mother, and the unaffected sibling showed no signs of $\mathrm{Cbl}$ deficiency despite the fact that each could probably synthesize only $50 \%$ as much normal IF as normal subjects is not surprising, since normal subjects usually synthesize much larger amounts of IF than is required to absorb the amount of $\mathrm{Cbl}$ that is absorbed from the diet and bile each day $(22,23)$.

Our in vitro studies with gastric juice and gastric biopsies from various members of family I suggested that the instability of the abnormal IF could be partially corrected by avoiding acid $\mathrm{pH}$ and performing incubations in the presence of saturating amounts of $\mathrm{Cbl}$. These observations suggested a new method for improving patients A-Cs' ability to absorb Cbl in Schilling tests. The new method involved the use of oral $\mathrm{NaHCO}_{3}$ to neutralize the patient's gastric juice and cobinamide, which blocks $\mathrm{R}$ protein, allowing the radioactive $\mathrm{Cbl}$ used in the Schilling test to become bound to the patient's IF immediately after the IF is secreted in the gastric juice (32). These maneuvers increased the mean value of the Schilling test in the three patients from 0.6 to $4.2 \%(P<0.05)$. They also illustrate how a more thorough understanding of the pathophysiology of a particular clinical entity can lead to new forms of therapy. In the present case, bicarbonate and cobinamide are not required for treatment, however, since all of the patients' symptoms can be corrected with monthly injections of $\mathrm{Cbl}$.

The detailed descriptions of two different abnormal IFs illustrate and reinforce the importance of IF's ability to facilitate the binding of $\mathrm{Cbl}$ to ileal receptors and the ability of IF to resist degradation by acid $\mathrm{pH}$ and various proteolytic enzymes. The search for and elucidation of other abnormal IFs can be expected to illustrate other properties of IF and is likely to provide new information concerning the synthesis and secretion of IF, as well as the function and fate of IF after IF-Cbl binds to ileal receptors, since none of these processes is well understood. The search for additional abnormal IFs is likely to be rewarding since recent studies (36) indicate that approximately two-thirds of patients with a congenital absence of functional IF in gastric juice have IF in their parietal cells. In addition, Rothenberg et al. (37) have recently observed a patient who may have an IF that is thermolabile with respect to $\mathrm{Cbl}$-binding and binds to ileal receptors with low affinity.

\section{Acknowledgments}

We thank Ms. Maria Ignacio for expert secretarial assistance.

This work was supported by U. S. Public Health Service grants RO1 AM21365 and RO1 AM30366 from the National Institute of Arthritis, Metabolic and Digestive Diseases.

\section{References}

1. Spurling, C. L., M. S. Sacks, and R. M. Jiji. 1964. Juvenile pernicious anemia. N. Engl. J. Med. 271:995-1003.

2. McIntyre, O. R., L. W. Sullivan, G. H. Jeffries, and R. H. Silver. 1965. Pernicious anemia in childhood. N. Engl. J. Med. 272:981-986.

3. Reisner, E. H., Jr., J. A. Wolff, R. J. McKay, Jr., and E. F. Doyle. 1951. Juvenile pernicious anemia. Pediatrics. 8:88-106.

4. Mollin, D. L., S. J. Baker, and I. Doniach. 1955. Addisonian pernicious anaemia without gastric atrophy in young man. Br. J. Haematol. 1:278-290.

5. Stevenson, T. D., J. A. Little, and L. Langley. 1956. Pernicious anemia in childhood. N. Engl. J. Med. 255:1219-1223.

6. Harris-Jones, J. N., H. T. Swan, and G. R. Tudhope. 1957. Pernicious anemia without gastric atrophy in the presence of free hydrochloric acid: report of case. Blood. 12:461-468.

7. Leikin, S. L. 1960. Pernicious anemia in childhood. Pediatrics. 25:91-100.

8. Lambert, H. P., T. A. J. Prankerd, and J. M. Smellie. 1961. Pernicious anaemia in childhood: report of two cases in one family and their relationship to aetiology of pernicious anaemia. Q.J. Med. 30:7190 .

9. Clement, D. H., C. A. Nichol, and A. D. Welch. 1961. Case of juvenile pernicious anemia: study of effects of folic acid and vitamin B $_{12}$. Blood. 17:618-631.

10. Waters, A. H., and M. E. B. Murphy. 1963. Familial juvenile pernicious anaemia: study of hereditary basis of pernicious anaemia. $\mathrm{Br}$. J. Haematol. 9:1-12.

11. Pearson, H. A., R. Vinson, and R. T. Smith. 1964. Pernicious anemia with neurologic involvement in childhood: report of case with emphasis on dangers of folic acid therapy. J. Pediatr. 65:334-339.

12. Moody, E. A. 1965. Juvenile pernicious anemia. Northwest Med. 64:191-193.

13. Herbert, V., R. R. Streiff, and L. W. Sullivan. 1964. Notes on vitamin $B_{12}$ absorption: autoimmunity and pernicious anemia. Relation of intrinsic factor to blood group substance. Medicine (Baltimore). 43: 679-687.

14. Dimson, S. B. 1966. Juvenile pernicious anemia. Arch. Dis. Child. 41:216-220

15. Miller, D. R., G. E. Bloom, R. R. Streiff, A. F. LoBuglio, and L. K. Diamond. 1966. Juvenile "congenital" pernicious anemia. Clinical and immunologic studies. N. Engl. J. Med. 275:978-983.

16. Lampkin, B. C., and A. M. Mauer. 1967. Congenital pernicious anemia with coexistent transitory intestinal malabsorption of vitamin B $_{12}$. Blood. 30:495-502.

17. McNicholl, B., and B. Egan. 1968. Congenital pernicious anemia: effects on growth, brain and absorption of $B_{12}$. Pediatrics. 42:149-156.

18. Yun, D. J., H. Lee, G. P. Chun, and K. Y. Lee. 1967. Juvenile pernicious anemia in sisters. Yonsei Med. J. 8:71-76.

19. Lillibridge, C. B., L. L. Brandborg, and C. E. Rubin. 1967. Childhood pernicious anemia: gastrointestinal secretory, histological, and electron microscopic aspects. Gastroenterology. 52:792-809.

20. Arthur, L. J. H. 1972. Juvenile pernicious anemia. Proc. R. Soc. Med. 65:10-11.

21. Fakatselli, N. M., B. G. Delta, E. Y. Hudaverdi, and D. Liakoff. 1978. Pernicious anemia in childhood. Am. J. Med. Sci. 276:144-151.

22. Chanarin, I. 1979. The Megaloblastic Anaemias. Blackwell-Mosby Book Distributors, St. Louis, MO. 2nd edition. 1-783.

23. Allen, R. H. 1975. Human vitamin $B_{12}$ transport proteins. Prog. Hematol. 9:57-84.

24. Nexo, E., and H. Olesen. 1982. Intrinsic factor, transcobalamin, and haptocorrin. In $\mathrm{B}_{\mathbf{1 2}}$. D. Dolphin, editor. John Wiley \& Sons, New York. 2(3):57-85.

25. Allen, R. H. 1982. Cobalamin (vitamin $B_{12}$ ) absorption and malabsorption. Viewpoints Digest. Dis. 14:17-20.

26. Katz, M., S. K. Lee, and B. A. Cooper. 1972. Vitamin B $B_{12}$ mal- 
absorption due to a biologically inert intrinsic factor. N. Engl. J. Med. 287:425-429.

27. Katz, M., C. S. Mehlman, and R. H. Allen. 1974. Isolation and characterization of an abnormal human intrinsic factor. J. Clin. Invest. 53:1274-1283.

28. Allen, R. H., B. Seetharam, E. R. Podell, and D. H. Alpers. 1978. Effect of proteolytic enzymes on the binding of cobalamin to $R$ protein and intrinsic factor. In vitro evidence that a failure to partially degrade $\mathrm{R}$ protein is responsible for cobalamin malabsorption in pancreatic insufficiency. J. Clin. Invest. 61:47-54.

29. Allen, R. H., and C. S. Mehlman. 1973. Isolation of gastric vitamin $B_{12}$-binding proteins using affinity chromatography. I. Purification and properties of human intrinsic factor. J. Biol. Chem. 248:3660-3669.

30. Gottlieb, C., K. S. Lau, L. Wasserman, and V. Herbert. 1965. Rapid charcoal assay for intrinsic factor (IF) gastric juice unsaturated $B_{12}$-binding capacity, antibody to $\mathrm{IF}$, and serum unsaturated $\mathrm{B}_{12}$-binding capacity. Blood. 25:875-884.

31. Roitt, I. M., and D. Doniach. 1969. In Textbook of Immunopathology. P. A. Miescher and H. J. Muller-Eberhard, editors. Grune \& Stratton, New York. 2:534-546.

32. Allen, R. H., B. Seetharam, N. C. Allen, E. R. Podell, and D. H. Alpers. 1978. Correction of cobalamin malabsorption in pancreatic in- sufficiency with a cobalamin analogue that binds with high affinity to $\mathbf{R}$ protein but not to intrinsic factor. In vivo evidence that a failure to partially degrade $\mathbf{R}$ protein is responsible for cobalamin malabsorption in pancreatic insufficiency. J. Clin. Invest. 61:1628-1634.

33. Levine, J. S., P. K. Nakane, and R. H. Allen. 1980. Immunocytochemical localization of human intrinsic factor: the nonstimulated stomach. Gastroenterology. 79:493-502.

34. Levine, J. S., P. K. Nakane, and R. H. Allen. 1981. Human intrinsic factor secretion: immunocytochemical demonstration of membrane-associated vesicular transport in parietal cells. J. Cell Biol. 90: 644-655.

35. Hooper, D. C., D. H. Alpers, R. L. Burger, C. S. Mehlman, and R. H. Allen. 1973. Characterization of ileal vitamin $B_{12}$-binding using homogeneous human and hog intrinsic factors. J. Clin. Invest. 52:30743083.

36. Levine, J. S., and R. H. Allen. 1985. Intrinsic factor within parietal cells of patients with juvenile pernicious anemia: a retrospective immunohistochemical study. Gastroenterology. 88:1132-1136.

37. Rothenberg, S. P., E. V. Quadros, E. W. Straus, and S. Kapelner. An abnormal intrinsic factor (IF) molecule: a new cause of "pernicious anemia" (PA). Blood. 64:4la. (Abstr.) 